\title{
Benchmarking the Investment Process of New Technology
}

\section{Persson}

\author{
Dept of Industrial Engineering, Lund University \\ P.O. Box 118, S-221 00 Lund, Sweden
}

\section{INTRODUCTION}

Use of new technology has not always been a success. In fact, rather many heavy capital investments have not provided the expected increase in productivity, and the announced profitability has not always been reached. Osterman (1991) showed that more advanced technology did not mean an increase in productivity, however human resource management was considered to be very important.

The fact that the expected influence from new technology has not been reached has been interpreted as a challenge for improvements in management support when evaluating investments in information technology and advanced manufacturing technology. Many articles have been published. In the streamline of suggested improvements, three different areas have been found:

1. Improvements of techniques used in the evaluation process. There are many articles which discuss improved evaluation techniques. Meredith \& Suresh (1986) and Soni et al (1992) have made summaries of the economic and analytical justification methods. Estimated probability (Azzone \& Bertele, 1989), or random variables, (Suresh, 1990) are suggested in order to take flexibility into account.

2. Strategic investment appraisal. The link to the strategy is focused (Noble, 1990; Slagmulder \& Bruggeman, 1991). The decision to invest is primarily based on an analysis of to what extent the suggested investment can support the actual strategy. This approach relates the investment to the business which will influence the way of working with the investment later on. Slagmulder et al (ibid.) found that the quality of the strategic analysis was the main critical success factor in their study (case studies).

Within this approach, recommendations for which quantitative and qualitative measures are to be used are dependent on the project. Meredith \& Suresh (ibid.) and Meredith \& Hill (1987) focus on four main approaches at the full integration level: technical importance, business objectives, competitive advantage, and research $\&$ development. Though basically in a critical mode 
concerning misuse of capital budgeting techniques, Clemons (1991) states that "sometimes we can do a net present value analysis... even for strategic investments and capture uncertainty through sensitivity analysis" p33. Sometimes a strategic investment can merely be seen as an option. A strategic approach is suggested for systems that directly contribute to the company's business objectives. (Burstein \& Pearson, 1990)

3. Focus on a champion. Ward(1990) emphasises the champion in the implementation process by referring to Schon(1967). Beatty (1992) found that successful implementation requires a skilled champion. Slagmulder et al (1991) found that a champion was not a sufficient condition for success.

\section{THE OBJECTIVE OF THE PROJECT}

In other studies have been found that new technology is working successfully with the human resource management applied in Japanese companies. (Osterman, 1991). There is, however, no research which penetrates the difference between the investment process of successful projects in new technology and the investment process when the project fails. This study will fill that gap.

The objective is to benchmark successful and less successful investment processes of new technology. Perhaps other countries than Sweden could be involved. Experience has been found to be very important in traditional capital investment processes (Persson, 1990) in Swedish companies as well as manager's perspective. Making successful investments in new technology, however, must not be dependant of experience. Instead, the old process may be an obstacle.

Hypothesis 1. When taking steps in technology or introducing new technology there is a need for new knowledge which is difficult to obtain by traditional educational efforts.

The hypothesis is that when making investments in new technology, experience based knowledge has to be replaced by a process of learning and influence, which creates the corresponding knowledge before the decision to invest is made. If so, this competence would influence, through a deeper analysis to understand what is possible and also make it easier to compare different levels of technology. Instead of making a judgement, the manager has to make the necessary arrangement in order to understand.

Hypothesis 2. The successful capital investments in new technology, have a process which includes learning and influence in the early stages.

The difficulties in the appraisal of new technology are the inabilities to concretise the effects from an investment. Persson, 1994, emphasise the understanding and insight which the managers would like to have when making a decision. Managers need to understand what the technology can offer from a business oriented point of view and what the demands of the 
investment will be in the different areas, in order for it to be a success. Competence is one example of an important area.

\section{METHODOLOGY}

To test the hypothesis data on successful and unsuccessful implementation processes of new technology is of interest.

The testing of the hypothesis can be made through surveys.

Cases are the traditional method used for gaining a deeper understanding in a complex environment and will be used in next phase.

\subsection{Survey}

The hypothesis is that there is a difference between the way people are involved in the investment process, which in itself is a benchmarking process. This hypothesis must first be tested.

In a survey, I want a method that uses the respondents answers. Traditional interviews are one possibility, but involves a lot of interpretative work

The conjoint method is a survey method which can take earlier answers into account by using of computer. There are benefits as well as disadvantages when answers are given through a computer. The benefits, besides the use of earlier data, are the structuring of data and hence less effort is needed in making the analysis. The disadvantages, above all, are that the selection of respondents will be influenced and restricted.

\subsection{Cases}

Cases is the traditional method used when making in depth studies. Benchmarking of a process also means a study to get understanding. Cases can be carried out as a longitudinal study as well as a reconstructing study. If it is a longitudinal study, the researcher can work passively as well as in an action mode.

Working in an action mode means that the outcome is dependent on the researcher's actions. Based on the hypothesis this could be actual. In order to be meaningful the quality has to reach an acceptable level, which means that the possibility to influence should be important. These actions, however, would be based on important performance indicators before the decision to invest is made. The performance indicators first has to be caught from a survey study.

\subsection{Conclusions on methodology}

The first goal of research is to test the hypothesis by a survey method. The conjoint method is preferred if possible and the objective is to get which criteria are important.

A second step may be to make deeper studies of the investment process in a company, which has had a successful investment process. The company (companies) will be chosed from the answers in the survey. 


\section{REFEREINCES}

G. Azzone and U. Bertele, Measuring the Economic Effectiveness of Flexible Automation: A New Approach. International Journal of Production Research, Vol.27, No.5, pp735-746, 1989.

C.A. Beatty, Implementing Advanced Manufacturing Technologies: Rules of the Road. Sloan Management Review, Summer, pp49-60, 1992.

M.C. Burstein and G. Pearson, Strategic Justification of Plant-Level Investments. Manufacturing Review, Vol 3, No 3, pp171-177, 1990.

E.K. Clemons, Evaluation of Strategic Investments in Information Technology. Communications of the ACM, January, p25, 1991.

T. Hill, Manfacturing Strategy. MacMillan, 1985.

J.R. Meredith and M.M. Hill, Justifying New Manufacturing Systems: A Managerial Approach. Sloan Management Review, Summer, pp49-61, 1987.

J. Merredith and N.C. Surech, Justification Techniques for Advanced Manufacturing Technologies. International Journal of Production Research, pp1043-1057, 1986.

J.L. Noble, A New Approach for Justifying Computer-Integrated Manufacturing. Journal of Cost Management Winter pp14-19, 1990

P. Osterman, New technology and Work Organization. Paper at the IVAConference "Technology and Investment - Critical Issues for the 90's, 1991.

I. Persson, Use of Information Technology in The Investment Process. WP 1990:20, Institute for Management of Innovation and Technology (within the Information Technology and Management Program), 1990.

I. Persson, The Capital Investment Process and New Technology. WP 1994:60, Institute for Management of Innovation and Technology (within the Information Technology and Management Program), 1994.

D. Samson, Manufacturing and Operations Strategy. Prentice Hall, 1991

D.A. Schon, Technology and Change: The New Heraclitus. Dell, 1967.

R. Slagmulder and W. Bruggeman, The Investment Decision Methodology and its Impact on the Success of Flexible Manufacturing Technologies. In Management and New Production Systems (EIASM) pp637-663, 1991. 
R.G. Soni, H.R. Parsaei, and D.-H. Liles, Economic and Financial Justification Methods for Advanced Automated Manufacturing: An Overview. In $H$ R. Parsai and A. Mital (eds.) Economics of Advanced Manufacturing Systems, Chapman \& Hall, pp3-19, 1992.

N.C. Suresh, Towards an Integrated Evaluation of Flexible Automation Investments. International Journal of Production Research, Vol 28, No9, pp1657-1672, 1990.

T.L. Ward, Role of Champions in Justification of Computer Integrated Manufacturing Systems. In H.R. Parsai, T.L. Ward and W. Karowski(eds.), Planning, Design, Justification and Costing. Elseiver Science Publishers B.V., pp123-131, 1990. 